\title{
ЧИСЛІВНИК В УКРАЇНСЬКІЙ ПОЕТИЦІ 3 ПОГЛЯДУ ПСИХОЛІНГВІСТИКИ
}

У статті з'ясовано роль і місие числівників у маркуванні поетичної картини світу письменників із кола шістдесятників - Івана Драча, Бориса Олійника, Миколи Вінграновського, Ліни Костенко як вияву їхної схильності до екстравертивної чи інтровертивної психологічної сутності, крізь призму якої окреслюється ідіостиль письменників.

За методологічну основу роботи править учення про мову як психічний феномен. За допомогою методів лінгвопсихологічної інтерпретаиіі, заsрунтованих на логіиі вербальної поведінки особистості та на розробленій К.-Г. Юнгом класифікацї психологічних типів, з'ясовано психологічне підsрунтя мовних особистостей аналізованих письменників.

Ключові слова: психолінгвістика, психологічні типи, інтроверти, екстраверти, поетичне мовлення, числівник.

Oleksenko O., Pavlova I. Numerals in Ukrainian Poetics from the Perspective of Psycholinguistics. The article defines the role and the place of numerals in the marking of the poetic picture of the world of the Sixtiers - Ivan Drach, Borys Olinyk, Mykola Vigranovskyi, Lina Kostenko as a manifestation of their propensity for an extravertive or introvertive psychological essence, which outlines the writers' idiostyle.

The methodological basis of the work is the doctrine of language as a mental phenomenon. The psychological background of the linguistic personalities of the above mentioned writers has been clarified with the help of such methods: methods of linguopsychological interpretations based on the logic of verbal behavior of an individual and on the classification of psychological types developed by K.- Jung; hypotheticaldeductive method; elements of the method of quantitative analysis, which made it possible to calculate the frequency of using different lexical and grammatical digits of numerals and their corresponding meanings; descriptive method used to systematize and clarify the specifics of the functioning of a numeral in a poetic text.

The study proposes and proves the hypothesis that speech introversion or extraversion may be based on the feature of the representation of a numeral as a core of an important lingophilosophical category of quantity. The linguistic personalities with an inclination to the extroversion actively use numerals in their direct meaning to indicate quantity and order when counting in the process of detailing the depicted environment. Speech is distinguished by the use of a variety of numerals with their formal and grammatical indicators. They even use compound numerals to denote specific quantity, that is not often the case in poetic speech. Extroversion prevails 
in the speech practice of I. Drach and B. Oliinyk. In the texts of those poets who are prone to introversion, the speech is characterized by the minimal numerical specification, the category of number acquires indeterminacy, is more symbolized, abstracted, the meanings associated with the meaning of "one" and in its opposition the semantics of "many" are priority. The introvertive type is clearly manifested in the poetic speech of M. Vingranovskyi and L. Kostenko.

The study shows that the relatedness of linguistic peculiarities to the corresponding psychotypes may also be based on the feature of the identity of the representation of a numeral. This information complements the picture of the idiostyles of these poets, allowing deeper insight into their inner world.

Key words: psycholinguistics, psychological types, introverts, extroverts, poetic speech, the numeral, linguistic personality, Sixtiers.

\section{Вступ}

Як відомо, ще Л. Щерба мовленнєву організацію індивіда розглядав як складний мовленнєвий механізм, що характеризується психофізіологічною природою, $є$ своєрідною обробкою мовленнєвого досвіду, слугує індивідуальним проявом вивідної з мовного матеріалу мовної системи (Щерба, 1974).

О. Селіванова, обгрунтовуючи структуру психолінгвістики, відповідно до положень О. Леонтьєва, виокремлює психолінгвістику мовної здатності, з-посеред головних проблем якої називає проблему вивчення мовної особистості (Селіванова, 2008: 242).

Цей термін, уведений В. Виноградовим, у своїй поняттєвій основі має ідеї, висловлені в роботах лінгвістів психологічного напряму Г. Штейнталя, В. Вундта, О. Потебні, О. Шахматова та ін. У цілісній структурі особистості комуніканта, що корелює з мовною особистістю, виокремлюють $я$ тілесне, $я$ соціальне, $я$ інтелектуальне, $я$ психологічне і $я$ мовномисленнєве (Селіванова, 2006: 370). Ю. Караулов виначає мовну особистість як категорію, що являє собою сукупність спроможностей і характеристик людини, що зумовлюють факт створення мовлення, дискурсу, тексту (Караулов, 1987: 3).

Спроможності й характеристики людини значною мірою залежать і від психічного типу нервової системи, що має в основі багато чинників. Як відомо, основи вчення про психологічні типи розроблені К. Юнгом (Юнг, 2016) і знайшли подальший розвиток у працях Г. Айзенка (Айзенк, 1999), Р. Кеттела (Cattel, 1996) та інших психологів. Вони виділили як основоположні дві психологічні установки: 
екстравертивну й інтровертивну. Крім того, психічний тип людини може бути розсудливим і чутливим, сенсорним чи інтуїтивним тощо, що теж ураховують психологи для впорядкування емпіричних даних. Відповідно, і класифікації типів на підставі різних рис чи факторів, що становлять структуру особистості, пропонують різні. Оскільки інтровертивний та екстравертивний типи в цій ієрархії визнаються визначальними, зупинимося на них як на основоположних у формуванні певної мовної особистості.

Мовні особистості письменників, зокрема поетів, заслуговують на особливу увагу дослідників, оскільки вони репрезентують високі зразки мовної і художньої культури, і вивчення поетичної картини світу, змодельованої крізь призму свідомості письменника, видається важливим для розуміння творчої лабораторії видатних носіїв української мови.

Психолінгвістичний аспект поетичного мовлення неодноразово був у полі зору представників Харківської лінгвістичної школи, зокрема наукової школи Л. Лисиченко (роботи Т. Ковальової, О. Олексенко, І. Павлової, Т. Скорбач).

Психолінгвісти помітили, що індивідуальний стиль репрезентації інформації мовцями встановлюється і з урахуванням кількості вжитих знаменних слів (Селіванова, 1999: 55; Залевская, 1999) та, додамо, їхнього семантичного навантаження. У лексиконі мовної особистості, як відомо, виокремлюється ядро й периферія, причому ядро співвідносять передусім з класом іменників, числівники ж належать до периферії лексикону, однак, на нашу думку, є виразними маркерами мовної особистості як репрезентанта того чи того психологічного типу. Тому актуальність дослідження визначається потребою встановлення кодових особливостей мовних одиниць периферійної зони лексикону для визначення специфіки психічного сприйняття довкілля, що віддзеркалюється в характері мовної особистості художника слова.

Матеріалом статті обрано мову творів поетів-шістдесятників як яскравих і талановитих творців української літератури, зокрема Івана Драча, Бориса Олійника, Миколи Вінграновського, Ліни Костенко.

Мета цієї розвідки - з'ясувати роль і місце числівників у маркуванні художньої картини світу поетів-шістдесятників як вияву їхньої схильності до інтровертивної чи екстравертивної психологічної 
сутності, крізь призму якої чіткіше окреслюється ідіостиль письменника.

Окреслена мета передбачає виконання таких завдань: 1) висвітлити основні риси інтровертивного й екстравертивного типів; 2) методом суцільної вибірки укласти картотеку числівникових слововживань у текстах поезій зазначених письменників; 3) установити кількісні пріоритети у вживанні тим чи тим поетом числівників та їхніх похідних; 4) з'ясувати контекстуальну семантику цих слововживань; 5) простежити специфіку відображення семантики вживання числівника у зв'язку з рисами вказаних психотипів.

\section{Методи дослідження}

Методологічною основою роботи $є$ вчення В. фон Гумбольдта, Е. Сепіра, Б. Уорфа, О. Потебні, Д. Овсянико-Куликовського, О. Бодуена де Куртене, О. Леонтьєва про мову як психічний феномен. Для розв'язання поставлених у роботі завдань застосовано такі методи дослідження: гіпотетико-дедуктивний, що зумовлює вибірку фактичного матеріалу, метод лінгвопсихологічної інтерпретації для з'ясування психологічного підгрунтя мовних особистостей аналізованих письменників, елементи методу статистичного аналізу для підрахунків частотності використання різних лексико-граматичних розрядів числівників і відповідних їхніх смислів, а також описовий метод для виявлення, систематизації та з'ясування специфіки функціювання числівника в художньому тексті.

\section{Виклад основного матеріалу}

Лінгвісти зауважують, що «мовна особистість характеризується певним ступенем володіння мовою, але, крім цього, й соціальним та особистісним вибором мовних засобів. Ознакою кожної мовної особистості є їі мовна спроможність, мовна і комунікативна компетенція, особливе світобачення, світосприйняття та світорозуміння, що відображається в індивідуальній мовній картині світу, а фіксується в когнітивній картині світу (Космеда, 2009: 133). Ці ознаки мовної особистості значною мірою загрунтовані на психологічних особливостях того чи того індивідуума.

К. Юнг, а пізніше Г. Айзенк, розробляючи вчення про психологічні типи, дали опис кожного з них у протиставленні, однак учені 
наголошували, що їхня типологія не є класифікацією людей, вона слугує тільки для упорядкування емпіричних даних про перевагу в психіці людей ознак того чи того типу. Наводимо деякі ключові слова, що розкривають різницю між цими двома типами. Екстраверти: товариськість, взаємодія, спрямування назовні, широта, екстенсивний, широкі зв'язки із зовнішнім світом, розкутий, комунікабельність, сприймає світ через дрібні елементи. Інтроверти: замкненість, зосередженість, внутрішнє спрямування, глибина, інтенсивний, обмежені зв’язки з зовнішнім світом, збереження енергії, замислений, сприймає світ блоками. Крім того, якщо людина схильна до прагматичного погляду на речі, хоче все оглянути й до всього доторкнутися, щоб переконатися й повірити, надає перевагу конкретним даним, для неї важливі факти й деталі, а не загальна тенденція - це сенсорний тип. Якщо ж людина інтуїтивно шукає взаємозв'язок між фактами, розуміє, що все у світі відносно, припускає існування невідомих факторів і сил, схильна висловлюватися алегорично, їй подобаються слова “приблизно” й “випадково”, - вона належить до інтуїтивного типу (Юнг, 2016; Айзенк, 1999; Cattel, 1996).

Далі спробуємо керуватися цими орієнтирами для визначення психологічного типу Івана Драча, Бориса Олійника, Миколи Вінграновського, Ліни Костенко, а тому й визначення специфіки їхніх поетичних картин світу в ракурсі вираження категорії кількості за допомогою її ядерної мовної одиниці - числівника та його похідних.

3 огляду на зв'язок із категоріями кількості, якості й оцінки числівник може зреалізовувати смисли відповідно до: 1) суто кількісної характеристики; 2) якісно-кількісної характеристики; 3) оцінювально-кількісної характеристики; 4) суто оцінювальної характеристики.

3 огляду на сучасну дискурсцентричну парадигму вивчення мовних одиниць числівник відносять до дискурсивних слів, які слугують для зв'язності тексту, виражають екстралінгвальну інформацію, смисли, що важко піддаються опису, бо природа лексичного значення числівників своєрідна - має високий рівень абстрагованості. Оскільки в мовознавстві поширена думка, що числівник, маючи “бідну” семну структуру, не здатен брати участі в моделюванні нових смислів, формуванні образної картини світу, що його художні функції не виразні, то цей аспект у дослідженні числівників залишається маловивченим. 
Однак беремо на себе сміливість стверджувати, що числівник має значний смислопороджувальний заряд, який у поетичній картині світу завдяки креативності окремих мовних особистостей має здатність виявлятися розмаїто, презентуючи поетичний задум автора.

Наголосимо, що добір фактичного матеріалу було здійснено шляхом суцільної вибірки контекстів із числівниками та їхніми похідними з масиву поетичних текстів обраних для аналізу поетів. Кількісні дані цих уживань наведено в таблиці.

\section{Таблиця вживань числівників}

у поезї̈ Б. Олійника, І. Драча, М. Вінграновського, Л. Костенко

\begin{tabular}{|c|c|c|c|c|c|c|c|}
\hline \multirow{3}{*}{ Автор } & \multirow{3}{*}{$\begin{array}{l}\text { Заг. } \\
\text { кіль- } \\
\text { кість }\end{array}$} & \multirow{3}{*}{$\begin{array}{c}\text { Порядко- } \\
\text { ві числів- } \\
\text { ники }\end{array}$} & \multicolumn{5}{|c|}{ Кількісні числівники } \\
\hline & & & \multirow{2}{*}{$\begin{array}{c}\text { Заг. } \\
\text { кількість }\end{array}$} & \multicolumn{4}{|c|}{ Розряди кількісних числівників } \\
\hline & & & & $\begin{array}{c}\text { власне } \\
\text { кільк. }\end{array}$ & $\begin{array}{l}\text { дро- } \\
\text { бові }\end{array}$ & збірні & $\begin{array}{c}\text { неозн.- } \\
\text { кільк. }\end{array}$ \\
\hline Б. Олійник & 797 & $\begin{array}{c}142 \\
(18 \%)\end{array}$ & $\begin{array}{c}655 \\
(82 \%)\end{array}$ & $\begin{array}{c}599 \\
(91 \%)\end{array}$ & - & $\begin{array}{c}38 \\
(6 \%)\end{array}$ & $\begin{array}{c}18 \\
(3 \%)\end{array}$ \\
\hline Л. Костенко & 708 & $\begin{array}{c}38 \\
(5 \%)\end{array}$ & $\begin{array}{c}670 \\
(95 \%)\end{array}$ & $\begin{array}{c}577 \\
(86 \%) \\
\end{array}$ & $\begin{array}{c}1 \\
(0,2 \%)\end{array}$ & $\begin{array}{c}21 \\
(3,2 \%)\end{array}$ & $\begin{array}{c}71 \\
(10,6 \%)\end{array}$ \\
\hline I. Драч & 254 & $\begin{array}{c}34 \\
(13 \%) \\
\end{array}$ & $\begin{array}{c}220 \\
(87 \%) \\
\end{array}$ & $\begin{array}{c}205 \\
(93 \%) \\
\end{array}$ & - & $\begin{array}{c}11 \\
(5 \%) \\
\end{array}$ & $\begin{array}{c}5 \\
(2 \%) \\
\end{array}$ \\
\hline М. Вінграновський & 170 & $\begin{array}{c}18 \\
(11 \%)\end{array}$ & $\begin{array}{c}152 \\
(89 \%)\end{array}$ & $\begin{array}{c}142 \\
(93 \%)\end{array}$ & - & $\begin{array}{c}5 \\
(3,5 \%) \\
\end{array}$ & $\begin{array}{c}5 \\
(3,5 \%) \\
\end{array}$ \\
\hline
\end{tabular}

Як свідчать наведені дані, найбільше й найрізноманітніше вживають числівники Б. Олійник і Л. Костенко. Близько 40 разів (приблизно однаково кожен) поети використовують числівники в сильних текстових позиціях заголовків віршів.

Найбільш послідовно в первинній (основній) функції для номінації кількості й порядку рахунку числівник використовують Б. Олійник та І. Драч (відповідно 50 і 45\%), менше це виражено в поезії Л. Костенко й М. Вінграновського (відповідно 30 і 28\%). У всіх поетів кількісні числівники домінують над порядковими (порядкові становлять лише 10-20\%). Серед кількісних більш поширені назви цілих чисел. Неозначено-кількісні числівники найбільш активні в дискурсі Л. Костенко (понад 10\%), збірні трапляються зрідка (від 3,5\% в Л. Костенко й М. Вінграновського до 5-6\% у І. Драча та Б. Олійника), дробових практично немає ні в кого.

За будовою переважають у поетичному вжитку прості числівники, проте складні й складені найбільш активно вводять у свій текст 
Б. Олійник та І. Драч (20-24\%), значно менше - Л. Костенко й М. Вінграновський (5 і 7\%).

За кількісними показниками використання лексико-граматичних розрядів числівників та їхніх розрядів за будовою ідіолекти поетів можна об'єднати й протиставити одночасно: об'єднуються Б. Олійник та I. Драч, їм можна протиставити Л. Костенко й М. Вінграновського.

Кількісні показники вживаності числівників, безумовно, важливий фактор у підтвердженні гіпотези щодо визначення моделей психотипів того чи того поета, але не самодостатній. Необхідно також зважати на смисли, породжувані авторами за допомогою числівників.

Поетичне мовлення Л. Костенко тяжіє до рис інтровертивного психотипу, воно характеризується абстрактним, а не конкретизованим сприйняттям кількості, кількість переважно є невизначеною, розмитою семантично, актуалізуються аксіологічні смисли, а також смисли, що вказують на внутрішнє «я», самотність, індивідуалізм. На цьому наголошували й інші дослідники мовлення Л. Костенко, зокрема О. І. Зінченко й Т. В. Коляда (Зінченко, \& Коляда, 1996). У її поезії виокремлюються “улюблені” часто вживані числівники один, два, mpu, чотири, n’яms, сто, тисяча, що репрезентують широку палітру смислів. Однак складені й дробові числівники практично не трапляються, що знов-таки характерно для інтровертів - відсутність вказівки на роздрібнені числа. Частіше, ніж в інших шістдесятників, використано неозначені числівники на зразок кілька, кількадесят, кільканадиять, кількоро, стонадиять, багато, мало, що теж відповідає критеріям мовленнєвої компетенції інтровертів, оскільки для них конкретна кількість не важлива, важлива вказівка на те, що денотатів, про які йдеться, багато чи мало: Тож навезуть возів стонадиять хмизу, ввіткнуть меча та як підпалять знизу!.. (Л. Костенко «Скіфська Одіссея»). Власне кількісні числівники сто, тисяча, сто тисяч Л. Костенко теж уживає з кількісно-оцінним значенням 'дуже багато’: ...Літ мені зроду тисячі тисяч... (Л. Костенко «Очі Василіска»), Сто різних справ кричало на папері (Л. Костенко «Маруся Чурай»).

Що суттєво для Л. Костенко - поетеси з явно інтровертивними рисами, так це те, що числівники з конкретною вказівкою на кількість зазвичай входять до складу синтаксичних конструкцій, які виражають приблизну кількість типу не менш як + числівник, щось по + 
числівник, а також зі вставними словами невпевненості, припущення на зразок можливо, може, мабуть: $А$ жо за спомин, тямили не дуже ми, / бо нам було ще років щзосв по сім... (Л. Костенко «Фото у далекий вирій»), Цю дівчину разів, мабуть, із вісім / коло млина вночі я споcmеріг (Л. Костенко «Маруся Чурай»). Такі випадки числівникового слововживання з інверсованим порядком слів, що виражає неточну кількість, у поезї Л. Костенко досить частотні (близько 6\%).

Л. Костенко має особливу здатність відчувати світ через переосмислення категорії кількості, числа, порядку, які дають їй змогу репрезентувати передусім внутрішній світ. Хоча числівник один найбільш уживаний у поезії і Л. Костенко, і Б. Олійника (по 43\%), але в мовленні Л. Костенко він більшою мірою тяжіє до прономіналізації, тобто семантика одиничності змінюється на дейктичність, що є вираженням відповідного ступеня інтимізації: А він один. Ліси $i$ далина. I тиша причаӥлась з усіх боків (Л. Костенко «Скіфська Одіссея»). Для вираження особливого рівня стану самотності поетеса послуговується редуплікованими формами один-один та один-однісінький: Він там живе в степу за вітряками, один-один, одвик і говорить... (Л. Костенко «Маруся Чурай»). Часом цей числівник набуває прикметникових смислів ознаки, якості, оцінки. Поетеса максимально використовує гаму демінутивних суфіксів, що, як відомо, є ознакою інтимізації змісту: Чуєи, роде мій, мій ріднесенькиц̆, хоч би вийиов хто хоч однесенький... (Л. Костенко «Чоловіче мій, запрягай коня!»); Тут, може, ідеться про долю краӥни! - а я про чиєсь там одненьке життя! (Л. Костенко «Маруся Чурай»).

Числівник один виражає смисли, притаманні інтровертам, дає змогу їм рефлектувати на події, явища довкілля, звертаючись до свого «я»: Ох, у житті свобода лиш єдина, одна свобода - та, изо у мені! (Л. Костенко «Берестечко»), Я ради иьього ладна жить. Всі інші хай проходять мимо, аби в повторах не згубить одне, своє, неповториме (Л. Костенко «В пустелі сизих вечорів...»). Загалом слід відзначити, що поетичне мовлення Л. Костенко насичене розмаїттям смислів, які здатен передавати числівник один у контекстах (див. Павлова, 2009), ці смисли демонструють прагнення зануритися в себе, людську внутрішню природу, почуття, емоції, психологічні стани, що підтверджує висловлену гіпотезу про належність психотипу Л. Костенко до інтровертів. 
Припускаємо, що психотип М. Вінграновського теж більшою мірою інтровертивний. Своєрідність використання числівника в тканині поетичного тексту свідчить про те, що це поет з мрійливою, романтичною натурою, занурений у себе, що відповідає платонівському психотипу - психотипу інтровертів. Його ідіостиль характеризується мінімальною числовою конкретизацією, переважає кількісна неозначеність, нечіткість у вимірах, прагнення за допомогою числівників виражати деяку абстракцію своїх уявлень (як і Л. Костенко): Іще одне! Малесеньке одне: Сховайте для поетів мої очі (М. Вінграновський «Ви чуєте? Ви чуєте - він спить!»). Поет утворює від числівників зменшено-пестливі похідні, що інтенсифікує вияв інтимізації (однесенький, обоєнько тощо: Вони ж собі обоєнько удвох Тихенько граються та сваряться тихенько... (М. Вінграновський «Спогад про війну»)). Виникають кількісно-оцінювальні, якісно-оцінювальні та оцінювальні смисли: Буде тобі сіно, і до сіна, І земля барвінкова, й поріг, А мені - дружина й Украйна, Сто тривог і тисяиа доріг! (М. Вінграновський «Де ти, мій коню з Дніпра-Дунаю?»), Я тиран,/ А ти мільйон тиранів (М. Вінграновський «Кінотриптих»). Крім того, використання числівника один більшою мірою пов'язане зі смислами “самотність”, “одинокість”, “занурення у власне я”, більш послідовно виражається особистісне начало: Іде чорний сум, а за ним суми, / Ще й одна журба плететься... (М. Вінграновський «Дума про британку»).

Усе зазначене дає змогу констатувати, що М. Вінграновський, як і Л. Костенко, належать до поетів, занурених у себе, що сприймають світ цілісно, не деталізуючи, у приблизному кількісному вимірі за основним протиставленням один - багато.

Як уже згадувалося, екстраверти зображують зовнішній світ, деталізуючи його. У цьому неабияка роль належить числівникам - словам, що безпосередньо конкретизують уявлення про довкілля і навіть про абстрактні поняття.

Поетичні тексти І. Драча та Б. Олійника засвідчують наявність великої кількості числівників: поети відповідно до (як ми припускаємо) свого екстравертивного психотипу прагнуть усе виміряти, вирахувати, пронумерувати, точно схарактеризувати, укласти життєву картину в систему з точними числовими характеристиками. Мовлення обох поетів вирізняється значним розмаїттям використаних числівників 
за їхніми формально-граматичними показниками: Три екзекутори та й иетвертий кат (I. Драч «Балада про Кармалюка»), Двадиятеро тине в гості Із рідної стороності, Двадиятеро у сні сняться... (І. Драч «Балада про стару»), Чекають, як дев'ять нормативних грамів Вженуть без докору і каяття (Б. Олійник «Від Білої хати до Білого дому...»), Три місяці, всі дев'яносто діб, коли життя ламалось, наче повінь, читав мені він «Кобзаря» напам'ять (Б. Олійник «У дзеркалі слова»), Все. Дев'ятнадиять десять за нью-йоркським. ...Давайте познайомимось, Америко (Б. Олійник «Від Білої хати до Білого дому»). За допомогою числівників вимірюють простір, час, вагу, явища природи, підраховують гроші, конкретизують вік людини, рахують людей і предмети, установлюють порядок перебігу подій.

Зазвичай у поезії зовсім не використовують складені форми числівників, але екстравертивність І. Драча й Б. Олійника виявляється в тому, що вони дають детальні кількісні характеристики конкретним реаліям довкілля: Рейсхкомісар України Еріх Кох, Нещзадний башист, «другий Сталін», Помер у затишній польській тюрмі 12 листопада 1986 року, маючи 92 роки... (І. Драч «Самообслуговування»), Шість тисяч сімсот вже вростають у грунт. А триста...на извинтар покласно ідуть (Б. Олійник «Урок»), Двадиять другого червня, Рівно в чотири нуль-нуль (Б. Олійник «Смертію смерть здолавши») тощо.

Неозначені числівники трапляються в обох поетів зрідка, однак простежується тенденція вживати власне кількісні числівники в значенні дуже великої кількості, створювати в такий спосіб гіперболу: Доріженька на сто тривог лягла, І шибениия в сто очей чигала (І. Драч «Безсмертна сивизна»), Та нагло тиша тріснула на сто крижин (Б. Олійник «Маяковському»), Я додому прийшов. Похиливсь, як верба. Триста лих мені дивляться в очі (Б. Олійник «Похорон учителя»), Я б узнав його серед мільйон мільярдів (Б. Олійник «Гора») тощо.

Поширений числівник у поетичному доробку цих авторів у сильній позиції заголовка вірша (у I. Драча - 9 таких позицій: «Січнева балада 1924 року», «Марія з України - № 62276: від Освенціму до Чорнобильської атомної», «Балада 018/133» та ін.; у Б. Олійника - 10: «Говорили-балакали дві верби за селом», «Чотири посвяти безсмертним», «П'ятий член трибуналу», «Дев'яте травня сорок п'ятого», «Береги двадцять першого віку» та ін.), що теж свідчить про увагу поетів до деталізації явищ і предметів світу. У поетичному доробку 
Л. Костенко й М. Вінграновського числівники в назвах віршів теж трапляються, але значно менше.

Лексико-граматичний клас числівників виразно виокремлюється в мовній і когнітивній картинах світу І. Драча та Б. Олійника, надає тексту конкретності, відображає прагнення поетів споглядати світ за допомогою конкретних категорій, що відповідає схильності їхньої психіки до екстравертивного типу.

\section{Висновки}

Евристичний потенціал категорії “мовна особистість”, що $є$ відгуком на актуальні потреби сучасної науки про мову й людину, як бачимо, далеко не вичерпано. Презентуючи синтез лінгвістичного та психологічного знання, ця категорія ставить перед лінгвістами завдання щодо врахування пропорцій, у яких власне мовне начало в дослідницькому підході повинно поєднуватися з психологічним.

Мета таких досліджень - це вияв лінгвопсихологічних ознак, сукупність яких дає змогу описати особливості мовленнєвої поведінки мовної особистості. У пошуках ключової риси мовленнєвого почерку, що дозволяє розкрити логіку вербальної поведінки особистості, сьогодні частково використовують розроблену К. Юнгом класифікацію психологічних типів, в основі якої лежить протиставлення інтроверсії та екстраверсіі.

Егоцентрично налаштована мовна особистість породжує тексти, ускладнені надмірною мотивацією словесного вибору. Звичайним “автографом" мовленнєвої інтроверсії $€$ вербалізована корекція свого мовленнєвого вчинку, що відображає стан “блукання” навколо денотата в пошуках оптимальної мовленнєвої форми. Інтроверсію видає потреба в самоконтролі, активна увага до образу свого “я”. Усе це не притаманне екстравертам, що й дає змогу стверджувати наявність особливого стилю інтроверсії чи, відповідно, екстраверсії як способу словесного реагування на довкілля, що продиктоване психологічною домінантою поета.

Це дослідження показує, що в основі віднесеності мовних особистостей до відповідних психотипів може лежати й ознака своєрідності репрезентації числівника як, власне, й інших частин мови, зокрема займенника (див. Олексенко, 2015). Однак це не абсолютизована ознака визначення психотипу, а лише гіпотеза про ще одну рису, 
за допомогою якої можна визначити психотипні пріоритети мовної особистості.

Отже, висновковуємо: мовні особистості, у яких переважає екстравертивність, активно використовують числівники в їхньому прямому значенні для номінації кількості й порядку при лічбі для деталізації довкілля, у їхньому художньому мовленні можливі складні й складені числівники зі значенням конкретної кількості; натомість у тих, де переважає інтровертивність, ці ознаки нівелюються, категорія кількості набуває невизначеності, більшою мірою символізується, абстрагується, на передній план виходять смисли, пов'язані зі значенням “один”, а також у його протиставленні із семантикою “багато”.

Уважаємо, що ці висновки потребують подальшого підтвердження за допомогою вивчення характеру функціювання інших класів мовних одиниць у мовленні тих чи тих особистостей.

\section{ЛІТЕРАТУРА}

1. Айзенк, Г. Ю. (1999). Структура тичности. Санкт-Петербург: Ювента; Москва: КСП+. 2. Загнітко, А., \& Михальченко, М. (2008). Основи психолінгвістики. Донецьк: ДонНУ. 3. Залевская, А. А. (1999). Введение в психолингвистику. Москва: Рос. гос. гуманит. ун-т. 4. Засєкіна, Л. В., \& Засєкін, С. В. (2002). Вступ до психолінгвістики. Острог: Вид-во Нац. ун-ту «Острозька академія». 5. Зінченко, О., \& Коляда, Т. (1996). «Вежа самотності»: позамовні смисли: До поезї̈ Ліни Костенко. Сучасність, 12, 110-115. 6. Караулов, Ю. Н. (1987). Русский язык и языковая личность. Москва: Наука. 7. Космеда, Т. А. (2009). Мовна спроможність, комунікативна компетенція, мовна особистість як проблемні питання сучасного українського мовознавства. Лінгвістична палітра (с. 129-140). Харків: ХНПУ імені Г. С. Сковороди. 8. Леонтьев, А. А. (1969). Язык, речь, речевая деятельность. Москва: Наука. 9. Лисиченко, Л. А., \& Скорбач, Т. В. (2001). Мовний образ простору і психологія поета. Харків: ХДПУ імені Г.С. Сковороди. 10. Олексенко, О. А. (2015). Прономінальність поетичного мовлення як ознака авторського стилю (на матеріалі творчості поетів-шістдесятників). Studia Ukrainika Posnaniensia, III, 181-189. 11. Павлова, I. А. (2009). Числівник у поетичному мовленні В. Стуса крізь призму його психотипу. Уч. зап. Тавр. нац. ун-та им. В. И. Вернадского, 22 (61), 435-440. 12. Селиванова, Е. А. (1999). Когнитивная ономасиология. Киев: Наук. думка. 13. Селіванова, О. (2006). Сучасна лінгвістика: термінологічна енциклопедія. Полтава: Довкілля-К. 14. Селіванова, О. О. (2008). Сучасна лінгвістика: напрями та проблеми. Полтава: Довкілля-К. 15. Щерба, Л. В. (1974). О трояком аспекте языковых явлений и об эксперименте в языкознании. В Языковая система и речевая деятельность (с. 235-267). Ленинград: Наука. 16. Юнг, К. Г. (2016). Психологические типь. Москва: Академ. проект. 17. Якобсон, Р. О. (1983). Поэзия грамматики и грамматика поэзии. В Семиотика (с. 462-482). Москва: Радуга. 18. Cattel Raymond, B. (1996). The scientific analisis of personality. Chicago: Aldine Pub. Co. 


\section{REFERENCES}

1. Ajzenk, G. Yu. (1999). Struktura lichnosti [Personality formation]. Sankt-Peterburg: Yuventa; Moskva: KSP+ [in Russian]. 2. Zahnitko, A., \& Mykhalchenko, M. (2008). Osnovy psykholinhvistyky [Basics of Psycholinguistics]. Donetsk: DonNU [in Ukrainian]. 3. Zalevskaya, A. A. (1999). Vvedenie v psikholingvistiku [Introduction to Psycholinguistics]. Moskva: Ros. gos. gumanit. un-t [in Russian]. 4. Zasiekina, L. V., \& Zasiekin, S. V. (2002). Vstup do psykholinhvistyky [Basics of Psycholinguistics]. Ostroh: Vyd-vo Nats. untu «Ostrozka akademiia» [in Ukrainian]. 5. Zinchenko, O., \& Koliada, T. (1996). «Vezha samotnosti»: pozamovni smysly: Do poezii Liny Kostenko [«Tower of Loneliness»: extralingual meanings: To Lina Kostenko's poetry]. Suchasnist - Modernity, 12, 110-115 [in Ukrainian]. 6. Karaulov, Yu. N. (1987). Russkij yazyk i yazykovaya lichnost' [Russian language and linguistic personality]. Moskva: Nauka [in Russian]. 7. Kosmeda, T. A. Movna spromozhnist, komunikatyvna kompetentsiia, movna osobystist yak problemni pytannia suchasnoho ukrainskoho movoznavstva [Linguistic ability, communicative competence, linguistic personality as problematic issues of modern Ukrainian linguistics]. Linhvistychna palitra - Linguistic palette (pp. 129-140). Kharkiv: KhNPU imeni H. S. Skovorody [in Ukrainian]. 8. Leont'ev, A. A. (1969). Yazyk, rech', rechevaya deyatel'nost' [Language, speech, speech activity]. Moskva: Nauka [in Russian]. 9. Lysychenko, L. A., \& Skorbach, T. V. (2001). Movnyi obraz prostoru i psykholohiia poeta [Linguistic expression of space and psychology of a poet]. Kharkiv: KhDPU imeni H. S. Skovorody [in Ukrainian]. 10. Oleksenko, O. A. (2015). Pronominalnist poetychnoho movlennia yak oznaka avtorskoho styliu (na materiali tvorchosti poetiv-shistdesiatnykiv) [The prominence of poetic speech as a feature of the author's style (based on the material of poets of the sixties)]. Studia Ukrainika Posnaniensia, III, 181-189 [in Ukrainian]. 11. Pavlova, I. A. (2009). Chyslivnyk u poetychnomu movlenni V. Stusa kriz pryzmu yoho psykhotypu [The numeral in the poetry of V. Stus thgrough the prism of his psychotype]. Uch. zap. Tavr. nats. un-ta im. V. Y. Vernadskoho - Sentific notes of V. Y. Vernadsky Tavrichesky National Universiti, 22 (61), 435-440 [in Ukrainian]. 12. Selivanova, E. A. (1999). Kognitivnaya onomasiologiya [Cognitive onomasiology]. Kiev: Nauk. dumka [in Russian]. 13. Selivanova, O. (2006). Suchasna linhvistyka: Terminolohichna entsyklopediia [Modern linguistics: Terminological encyclopedia]. Poltava: Dovkillia-K [in Ukrainian]. 14. Selivanova, O. O. (2008). Suchasna linhvistyka: napriamy ta problemy [Modern linguistics:areas and problems]. Poltava: Dovkillia-K [in Ukrainian]. 15. Shherba, L. V. (1974). O troyakom aspekte yazykovykh yavlenij i ob ehksperimente v yazykoznanii [About the three-pronged aspect of linguistic phenomena and the experiment in linguistics]. In Yazykovaya sistema i rechevaya deyatel'nost' - Linguistics and speech activity (pp. 235-267). Leningrad: Nauka [in Russian]. 16. Yung, K. G. (2016). Psikhologicheskie tipy [Psychological types]. Moskva: Akademicheskij proekt [in Russian]. 17. Yakobson, R. O. (1983). Poehziya grammatiki i grammatika poehzii [Poetry of grammar and grammar of poetry]. In Semiotika - Semiotics (pp. 462-482). Moskva: Raduga [in Russian]. 18. Cattel Raymond, B. (1996). The scientific analisis of personality. Chicago: Aldine Pub. Co [in English].

Олексенко Олена Андріївна - кандидат філологічних наук, професор, професор кафедри української мови, Харківський національний педагогічний університет імені Г. С. Сковороди; вул. Валентинівська, 2, Харків, 61168, Україна. 
Tel.: +380972896846

E-mail: oleksenkoolena@gmail.com

http://orcid.org/0000-0002-6541-8040

Oleksenko Olena Andriivna - Candidate of Philological Sciences (Ph.D.), Full Professor, Professor at the Department of Ukrainian Language, H. S. Skovoroda Kharkiv National Pedagogical University; 2 Valentynivska Str., Kharkiv, 61168, Ukraine.

Павлова Інна Андріївна - кандидат філологічних наук, доцент, доцент кафедри української мови, Харківський національний педагогічний університет імені Г. С. Сковороди; вул. Валентинівська, 2, м. Харків, 61168, Україна.

Tel.: +38-067-571-09-09

E-mail: pavlovainna2005@gmail.com

http://orcid.org/0000-0006-0898-514X

Pavlova Inna Andriivna - Candidate of Philological Sciences (Ph.D.), Docent, Associate Professor at the Department of Ukrainian Language, H. S. Skovoroda Kharkiv National Pedagogical University; 2 Valentynivska Str., Kharkiv, 61168, Ukraine.

Надійшла до редакції 9 березня 2021 року

\section{CITATION}

ДСТУ 8302:2015: Олексенко О. А., Павлова І. А. Числівник в українській поетиці з погляду психолінгвістики. Лінгвістичні дослідження: зб. наук. пр. Харк. нац. пед. ун-ту імені Г. С. Сковороди. Харків, 2021. Вип. 54. Ч. II. С. 112-125. DOI: https://doi. org/10.34142/23127546.2021.54.2.11

APA: Олексенко, О. А., \& Павлова, І. А. (2021). Числівник в українській поетиці з погляду психолінгвістики. Лінгвістичні дослідження, 54 (II), 112-125. DOI: https://doi. org/10.34142/23127546.2021.54.2.11 